\title{
Corticosteroid - an uncertainty in management of sepsis
}

\author{
Kanica Yashi \\ Department of Epidemiology, University of Pittsburgh, Pittsburgh, PA 15232, USA. \\ Address for correspondence: Dr. Kanica Yashi, Department of Epidemiology, University of Pittsburgh, Pittsburgh, PA 15232, USA. \\ E-mail: kay42@pitt.edu
}

Sir,

The purpose of this letter is to review the literature and bring the facts related to ambiguity in the use of corticosteroid in the management of sepsis.

Sepsis is defined as systemic response to infection and is diagnosed as per ACCS/SCCP consensus conference committee, 1992 guidelines. ${ }^{[1]}$ Progression of sepsis to septic shock is caused by series of immune responses. ${ }^{[2]}$ For many decades in the past steroids have been used in the management of sepsis but there has been an ambiguity in their use in septic shock, doses, duration of therapy effectiveness. However, recent studies have shown it to be effective in septic shock associated with "relative adrenal insufficiency". ${ }^{[3]}$ Cortisol increases at times of physiological stresses (e.g. sepsis, major injury, surgery, burns) due to activation of the hypothalamus pituitary axis. Suboptimal cortisol production during the septic shock has been termed as relative adrenal insufficiency and has been related to increased mortality in patients with sepsis but its actual existence remains controversial. The biochemical diagnosis of adrenal insufficiency by adrenocorticotropic hormone $(\mathrm{ACTH})$ tests were thought to be unreliable in critically ill patients. Also, measuring total cortisol may not be accurate in severely ill patients due to fluctuating levels of cortisol binding globulins. ${ }^{[4,5]}$

Several studies are available that provides clinical evidences related to the use of corticosteroids in sepsis. The French trial, ${ }^{[6]}$ in a randomized control trial on 229 patients, revealed that there was reduction in 28-day mortality on treatment with low dose corticosteroids (LDCs). Those who responded to ACTH stimulation test (maximum increase in serum cortisol of $>9 \mu \mathrm{g} / \mathrm{L}$ ) did not show

\begin{tabular}{|l|l|}
\hline \multicolumn{2}{|c|}{ Access this article online } \\
\hline Quick Response Code: & Website: \\
\hline & www.parjournal.net \\
\cline { 2 - 2 } & \\
\hline
\end{tabular}

any significant difference in 28-day mortality. The median time to vasopressor withdrawal and shock reversal was 9 days in the placebo group and was 7 days in treatment group $(P=0.01) .^{[3,4]}$ The strength of the study was the big sample size and the randomization, however, the use of both glucocorticoid and a mineralocorticoid was a marked weakness making distinctions between the effects of each drug difficult. ${ }^{[1]}$

Keh et $a l .^{[7]}$ performed a randomized double blinded placebo controlled crossover trial on 40 patients with septic shock to investigate the effects of LDC (100 mg bolus followed by $10 \mathrm{mg} / \mathrm{h}$ for the rest of 3 days) on immunologic parameters and hemodynamic parameters. It was seen that plasma cortisol levels increased to 5 folds in each group and were associated with stabilization of hemodynamic parameters. After $24 \mathrm{~h}$ of administration of corticosteroid the plasma concentration of interleukin-6 (IL-6), IL-8, IL-10 and tumor necrosis factor (TNF-1) and TNF-2 were significantly lower in the first group (received hydrocortisone) compared to the second one (did not receive hydrocortisone) $(P=0.01)$.

The strength of the study was that each patient received the intervention and served as his or her own control. However, the study was limited by the fact that hypothalamic-pituitary-adrenal axis was not addressed in this study. ${ }^{[1]}$

CORTICUS $^{[8]}$ has evaluated the efficacy of LDC in a broad population of patients (regardless of adrenal function) within $72 \mathrm{~h}$ of onset of shock. A total of 499 patients were randomized to treatment $(50 \mathrm{mg}$ hydrocortisone bolus every $6 \mathrm{~h}$ for 5 days, then $50 \mathrm{mg}$ hydrocortisone every

This is an open access article distributed under the terms of the Creative Commons Attribution-NonCommercial-ShareAlike 3.0 License, which allows others to remix, tweak, and build upon the work non-commercially, as long as the author is credited and the new creations are licensed under the identical terms.

For reprints contact: reprints@medknow.com

How to cite this article: Yashi $\mathrm{K}$. Corticosteroid - an uncertainty in management of sepsis. Plast Aesthet Res 2015;2:284-5.

Received: 28-11-2014; Accepted: 19-01-2015 
$12 \mathrm{~h}$ for 3 days and finally $50 \mathrm{mg}$ hydrocortisone every $24 \mathrm{~h}$ for 3 days $)^{[9]}$ or placebo groups. The results indicated no significant difference in mortality between treatment and the placebo group. But shock reversal was achieved more quickly in treatment group compared to the placebo group, regardless of the adrenal function $(P=0.001)$. However, the proportion of patients, in whom shock reversal was achieved, was similar between the 2 groups. There was also evidence of increased risk of superinfection in treatment group (combined odds ratio: 1.37; 95\% confidence interval: 1.05-1.79). The strength of the study was its large sample size, randomization and power of study was $80 \%$. The limitation of this study is that the treatment group received steroids as late as $72 \mathrm{~h}$. Earlier studies have shown that steroids have been beneficial only if given early $(<8 \mathrm{~h}) \cdot{ }^{[9]}$

All meta-analysis confirmed improved shock reversal with LDC use. ${ }^{[3]}$ Subsequent analysis found that severely ill patients were more likely to benefit from corticosteroid therapy. One analysis suggested that it may be harmful in less ill patients. ${ }^{[3]}$

While on steroids, according to a previous study done, ${ }^{[10]}$ there was a certain increase in side effects of secondary infections, gastrointestinal bleeding and increased blood glucose. However, these problems could be due to terminal illness. This probably indicates the need for a larger clinical trial. ${ }^{[2]}$

Current recommendations ${ }^{[3,11,12]}$ suggest:

- Administering intravenous corticosteroid therapy (200-300 mg/day) to adult patients with severe septic shock (defined as a systolic blood pressure less than $90 \mathrm{mmHg}$ for more than $1 \mathrm{~h}$ despite both adequate fluid resuscitation and vasopressor administration);

- Not administering the corticosteroid to patients without shock or patients with less severe shock (defined as those in whom fluid resuscitation and vasopressor therapy have restored hemodynamic instability);

- ACTH test prior to administering steroids in sepsis is not recommended;

- Typically administer hydrocortisone for 57 days and taper the dose as guided by the clinical response.

The impairment of hypothalamic-pituitary-adrenal axis in sepsis has not been resolved yet.

The most uniform finding by almost all trials is that corticosteroid may accelerate shock reversal. At this time, the most supported view is LDC should be administered to those patients who are in septic shock and unresponsive to fluids and vasopressor administration.

Review of the literature indicates the need to conduct carefully planned clinical trials to resolve controversies and to provide a more reliable result. ${ }^{[13]}$

\section{Financial support and sponsorship \\ Nil.}

\section{Conflicts of interest}

There are no conflicts of interest.

\section{REFERENCES}

I. Bone RC, Balk RA, Cerra FB, Dellinger RP, Fein AM, Knaus WA, Schein RM, Sibbald WJ. Definitions for sepsis and organ failure and guidelines for the use of innovative therapies in sepsis. The ACCP/SCCM Consensus Conference Committee. American College of Chest Physicians/Society of Critical Care Medicine. Chest 1992;101:1644-55.

2. Yarema TC, Yost S. Low-dose corticosteroids to treat septic shock: a critical literature review. Crit Care Nurse 201 1;31:16-26.

3. Gesensway D. Why steroids are making a comeback for treating septic shock. Todays Hospitalist 2006;5. Available from: http://www.todayshospitalist.com/ index.php?b=articles_read and $\mathrm{cnt}=176$. [Last accessed on 2014 Jun 02].

4. David KA, Mancebo J. Corticosteroid Therapy in septic shock. UpToDate 20I4; I. Available from: http://www.uptodate.com/contents/corticosteroidtherapy-in-septic-shock. [Last accessed on 2015 Jan II].

5. Hamrahian AH, Oseni TS, Arafah BM. Measurements of serum free cortisol in critically ill patients. N Engl J Med 2004;350:1629-38.

6. Annane D, Sébille V, Charpentier C, Bollaert PE, François B, Korach JM, Capellier G, Cohen Y, Azoulay E, Troché G, Chaumet-Riffaud P, Bellissant E. Effect of treatment with low doses of hydrocortisone and fludrocortisone on mortality in patients with septic shock. JAMA 2002;288:862-7I.

7. Keh D, Boehnke T, Weber-Cartens S, Schulz C, Ahlers O, Bercker S, Volk HD, Doecke WD, Falke KJ, Gerlach H. Immunologic and hemodynamic effects of "low-dose" hydrocortisone in septic shock: a double-blind, randomized, placebo-controlled, crossover study. Am J Respir Crit Care Med 2003; 167:5 I 2-20.

8. Sprung CL, Annane D, Keh D, Moreno R, Singer M, Freivogel K, Weiss YG, Benbenishty J, Kalenka A, Forst H, Laterre PF, Reinhart K, Cuthbertson BH, Payen D, Briegel J; CORTICUS Study Group. Hydrocortisone therapy for patients with septic shock. N Engl J Med 2008;358: I I I-24.

9. Toma A, Stone A, Green RS, Gray S. Steroids for patients in septic shock: the results of the CORTICUS trial. CJEM 20II;I3:273-6.

10. Cronin L, Cook DJ, Carlet J, Heyland DK, King D, Lansang MA, Fisher CJ Jr. Corticosteroid treatment for sepsis: a critical appraisal and meta-analysis of the literature. Crit Care Med 1995;23:1430-9.

II. Gandhi NR, Asudani DG. What is the role of steroids in septic shock? Hospitalist 2012;5. Available from: http://www.the-hospitalist.org/article/ what-is-the-role-of-steroids-in-septic-shock/. [Last accessed on 2015 Jan II].

12. Dellinger RP, Levy MM, Rhodes A,Annane D, Gerlach H, Opal SM, Sevransky JE, Sprung CL, Douglas IS, Jaeschke R, Osborn TM, Nunnally ME, Townsend SR, Reinhart K, Kleinpell RM, Angus DC, Deutschman CS, Machado FR, Rubenfeld GD, Webb SA, Beale RJ, Vincent JL, Moreno R; Surviving Sepsis Campaign Guidelines Committee including the Pediatric Subgroup. Surviving sepsis campaign: international guidelines for management of severe sepsis and septic shock: 2012. Crit Care Med 2013;41:580-637.

13. Vincent JL. Steroids in sepsis: another swing of the pendulum in our clinical trials. Crit Care 2008;12:141. 